A C G publications

Rec. Nat. Prod. 12:1 (2018) 1-13

records of natural

products

\title{
Phytochemistry and Pharmacology of Genus Indigofera: A Review
}

\author{
Taj Ur Rahman $\odot^{1,3^{*}}$, Muhammad Aurang Zeb $\odot^{2^{*}}$, Wajiha Liaqat ${ }^{3}$, \\ Muhammad Sajid $\odot^{2}$, Sajjad Hussain $\odot^{1}$ and M. Iqbal Choudhary $\odot^{4}$ \\ ${ }^{I}$ Department of Chemistry, Mohi-Ud-Din Islamic University, AJ\&K, Pakistan. \\ ${ }^{2}$ Department of Biochemistry, Hazara University, Mansehra, Pakistan \\ ${ }^{3}$ Institute of Chemical Sciences, University of Peshawar, Peshawar 25120, K.P.K, Pakistan \\ ${ }^{4}$ International Center for Chemical and Biological Sciences, H.E.J. Research Institute of Chemistry, \\ University of Karachi, Karachi-75270, Pakistan
}

(Received December 31, 2016; Revised July 24, 2017; Accepted July 29, 2017)

\begin{abstract}
In this review, the existing literature data on the phytochemical and biological studies of the genus Indigofera are outlined with 71 references. Up till now, 65 compounds were secluded from various species of genus Indigofera. The chemical components are mostly terpenoids, flavonoids and nitro group containing compounds, together with steroids and others. The metabolites and crude extracts of the genus indigofera were found to exhibit various bioactivities including, antimicrobial, insecticidal, phytotoxic, antiulcergenic, hepatotoxic, teratogenic and cytotoxicity. Other constituents isolated from the genus Indigofera displayed inhibitory activity against the enzyme lipoxygenase and gastrointestinal activity. This review represents a brief description of the total Phytochemical and Pharmacological activities of genus Indigofera as well as chemotaxonomic classification of chemical constituents.
\end{abstract}

Keywords: Phytochemistry; Indigofera; bioactivity; pharmacology. (C) 2017 ACG Publications. All rights reserved

\section{Introduction}

Plants play a major role in the maintenance of life on the planet earth. They convert simple substances into complicated entities producing chemicals that are essential for human health. Medicinal plants have been used as folk medicines by the people throughout the world [1]. From ancient time man has used plants for food, shelters and to treat various common diseases. Even, nowadays medicinal plants are widely used in a variety of products; such as pharmaceutical, dermaceutical and nutraceuticals products. The greatest demand and wide use of herbal products have become a major trade in the world by developing expensive medicines to treat various diseases. One of the ancient health core known to the human beings are the herbal medicines. In this modern era $20 \%$ of all prescription drugs still come from trees, shrubs or herbs, which are either directly obtained from the plant extracts or synthesized to mimic compounds derived from plants. The rural population of both Asian and African countries routinely uses herbs for the treatment of various diseases. In fact, many of the prescriptions used by traditional healers provide effective treatment for a variety of diseases but the role of the indigenous systems of medicine in national health programs has remained a subject of controversy. One group of professionals use the traditional system of medicine and claim that they have a remedy for almost every disease that exist, while modern system of medicine on the other hand rejects completely the entire indigenous system. The truth somewhat lies in between, and it is a need of the day to learn from each other's experiences, which

*Corresponding authors:E-Mail:Taj_urrehman81@yahoo.co.uk ; Muhammad_aurangzeb@hotmail.com 
would be essential for the well-being of human beings. It is therefore necessary that user of modern system of medicine must take an unbiased scientific look at the herbal concoctions to evaluate their usefulness for specific diseases. Before the discovery of antibiotics, infections were the most common 55 causes of mortality. Quinine alkaloid was the first chemical compound isolated from the bark of Cinchona tree (Cinchona officinalis) that effectively controlled certain fevers caused by malaria [1].

In the $18^{\text {th }}$ century a folk medical practitioner Reverend Edward Stone used to treat fever by utilizing the bark of white willow (Salix alba) with the same bitter taste like Cinchona. The principle responsible for controlling fever in willow bark was salicin, an analog of salicylic acid. Other closely related natural compounds were successively discovered and found to relieve fever, pain, swelling, gout, rheumatic fever and arthritis. A drug reserpine isolated from roots of Rauvolfia serpentinae was used in the treatment of hypertension, snakebite and mental illness. Examples of other valuable drugs from natural sources includes opiates and pilocarpine used for glaucoma, dry-mouth syndrome while vincristine and vinblastine obtained from Catharanthus roseus prescribed for pediatric leukemia and Hodgkin's disease respectively, which shows that medicinal plants have the valuable source of medicinal agents since time immemorial and Still continue to play a dominant role in primary health care. Keeping in view the importance of medicinal plants a review on genus indigofera was hoarded to further highlight the medicinal potential of various species of this genus to the researcher. The genus Indigofera, contains 300 species. All of these are herbs or shrubs, dispersed all through the tropical regions of the earth. In Pakistan it is epitomized by 24 species [2].

The genus Indigofera belongs to family, Fabaceae which is ranked the third largest family of the blossoming plants after Orchidnaceae and Asteraceae with approximately 650 genera and 18000 different species. The family in overall is characterized by the pod (legume) type of fruit developing from a single carpal with marginal placentation. The family Fabaceae is divided in to three sub-families (Caesalpiniodeae, Mimosoideae, Faboideae). In Pakistan, the species of genus Indigofera are found in mountainous areas of North West Frontier Province, Azad Jammu and Kashmir, Northern Areas of Dir, from 1500 to 3000 meters [3]. In India, some species are available in Himalayas, Kasi Afghanistan and W. China [4]. Fast-growing when young but slowing with age [5]. Tolerates light shade [6]. A tall shrub, $2.5 \mathrm{~m}$, covered bristly white hairs, copiously branched shrub with short imaripinnate, leaflets 9-33; flowers in axillary racemes, in erect often almost stalk less Oleg and Rix, (1985) bright red or rosy or radish purple [3,4] standard petal sessile, stamens diadelphous; pod cylindrical 10-12 seeded [3] have a vanillas cent [7]; flowers are mostly $6-10 \mathrm{~mm}$; calyx bristal haired, with lobes as tubes; bracts minute. Leaves and leaflets very variable, leaflets elliptic to oblanceolate, mostly $4-12 \mathrm{~mm}$, with white hairs. Pod $1.3-2.5 \mathrm{~cm}$, straight, hairless [8].

In reported works extensive work has been done on various species of the genus Indigofera. For instance, Indigofera oblongifolia has shown its antimicrobial [9] hepatoprotective [10] and lipoxygenase inhibitory activity [10]. Abubakar et al. has reported the snake-venom neutralizing bustle of Indigofera pulchra [11]. Antioxidant and free radical scavenging and anti-dyslipidemic actions of Indigofera tinctoria has also been reported [12,13]. Indigofera emarginella has shown in-vitro antimalarial action against Plasmodium falciparum. Chakrabarti et al. have reported the antidiabetic activity of Indigofera mysorens [14]. Whole plant is used in hepatitis, whooping cough [3] antispasmodic [15], tonic [16], the extract prevents the development of hypoglycemia in the mouse [17]; the plant leaves, flowers and tender shoots are cooling and demulcent, they are used in the form of leprosery and tumorous infection. The leaves are applied to abscesses. The roots are chewed in toothache and lethargy [16]. The alcoholic extract of the dried shoots has reported anti-inflammatory action [18]; the root bark is chomped in the mouth to relieve the abdominal pain [7]; leaves, bark and roots have antibacterial potency [19, 15].

\section{Chemical Constituents}

Compounds 1-65 are the known chemical constituents isolated from the genus Indigofera (Table 1, Figure 1). They are commonly flavonoids, especially, flavonoids glycosides. Many lignin and a few of other constituents including alkaloids, steroids, fatty acids containing amino group. 
Rahman et.al., Rec. Nat. Prod. (2018) 12:1 1-13

1. Flavonoidal compounds isolated from the Indigofera species; among the reported compounds, (129) are flavonoids isolated mainly from I. hebepetala, I. arrecta, I. pseudotinctoria, I. suffruticosa, I. hetrantha Wall, I. tinctoria, I. zollingeriana Miq, I. hebepetala Benth and I. kirilowi.

2. Nitro group containing compounds; which included compounds (30-34) were isolated from $I$. linnaei, I. endecaphylla, I. Suffruticosa, I. spicata and I. endecaphylla.

3. Amide; among the reported compounds (35-37) were isolated from I. pseudomonas, I. tinctoria, I. spicata and I. endecaphylla.

4. Steroidal compounds; which included compound (38-42) were isolated from I. pseudotinctoria and I. kirilowi.

5. Keto compounds; which further included compounds (43-45) containing keto group were isolated from I. pseudotinctoria and I. longeracemosa.

6. Keto flavonoid; included one compound (46) was isolated from I. suffruticosa.

7. Lignin; the compounds (47-48) were isolated from I. pseudotinctoria belongs to lignin's.

8. Alkaloids; the compound (49) was isolated from I. tinctoria, I. suffruticosa and I. truxillensis Kunth.

9. Terpenoids; the compounds (50-51) were isolated from I. longeracemosa Boiv. ex. Baill. and I. hetrantha.

10. Miscellaneous compounds; (52-53) were isolated from I. longeracemosa, I. oblongifolia Forssk. and I. hetrantha.

11. Toxic constituents (54-56) were isolated from of I. spicata

12. The three known rotenoids (57-59) were isolated from I. spicata.

13. A known chalcone $(\mathbf{6 0})$ was isolated from I. spicata

14. A known Nitropropanoyl compound (61) was isolated from I. suffriticosa

15. Bezofurans (62-63) were isolated from I. microcorpa.

16. A Cerebroside (64) was isolated from $I$. heterantha

17. An Ester (65) was isolated from I. heterantha

The data given above revealed chemotaxonomic classification of the chemical constituents in various species of genus indigofera.

\section{Biological Activities}

The genus Indigofera is known for the medicinal important due to a rich source of secondary metabolites such as flavonoids, triterpenoids, lignins and steroids. Based on structure activity relationship the biological activities of different class of compounds isolated from various species of the genus Indigofera are highlighted below. Indirubin isolated from I. suffruticosa proved to be excellent inhibitor in mice against lewis lung carcinoma and walker 256 carcinosarcoma [59]. Indispicine isolated from both I. spicata and I. endecaphylla (Posses good hepatotoxic and teratogenic activity [61]. While bovinocidin obtained from I. endecaphylla has showed moderate activity against mycobacterium tuberculosis [62]. Louisfieserone isolated from I. suffruticosa has antibacterial stroke against vague gram-positive and gram-negative microorganisms [65]. The isolated compound Hetranthin A displayed in vitro lipoxygenase inhibitory potential with an $\mathrm{IC}_{50}$ value of $2.1 \mu \mathrm{g} / \mathrm{mL}$ [28]. Fat food treated with a mixture of semiglabrin and pseudosemiglabrin (20:80) keeps significant reductions in plasma triglycerides $(60 \%)$, as well as completes cholesterol (19\%), along with an upsurge in high density lipoprotein (8\%) [29]. Indigo, a 2,2'-bisindole alkaloid is a main component of I. tinctoria, used as a blue dye. A 2,3'-isomer of indigo and insignificant component of I. tinctoria, indirubin, was documented as the active ingredient present in "Dang Gui Lu Hui" pills, containing eleven outmoded Chinese medicinal herbs. "Dang Gui Lu Hui" pills which are used in outmoded Chinese medicine to cure chronic myelogenous leukemia [40-41]. 
Table 1. Compounds isolated from the species of the genus Indigofera

\begin{tabular}{|c|c|c|c|}
\hline S. No. & Compound Name & Source & Ref \\
\hline \multicolumn{4}{|c|}{ Flavonoidal compounds } \\
\hline 1 & $(+)-5^{\prime \prime}$-deacetylpurpurin & I. spicata & {$[20]$} \\
\hline 2 & (+)-5-methoxypurpurin & I. spicata & {$[20,21]$} \\
\hline 3 & $(+)$-purpurin & I. spicata & {$[22,23]$} \\
\hline 4 & (2S)-2,3-dihydrotephroapollin C & I. spicata & [20] \\
\hline 5 & (2S)-2,3-dihydrotephroglabrin & I. spicata & [20] \\
\hline 6 & $\begin{array}{l}\text { (2S)-7-methoxy-8-(3-methoxy-3- methylbut- } \\
\text { 1-enyl) flavanone }\end{array}$ & I. spicata & {$[42]$} \\
\hline 7 & Kaempferitrin & I. arrecta & {$[24]$} \\
\hline 8 & Kaempferol 3,7diarabinoside & I. hebepetala & [25] \\
\hline 9 & Kaempferol 7-alloside & I. hebepetala & [25] \\
\hline 10 & $\begin{array}{l}\text { Triflin;2"'-O- } \beta \text {-L-ramnopyranosyl,7-O- } \beta-\mathrm{L}- \\
\text { arabinofuranoside }\end{array}$ & I. hebepetala & {$[26]$} \\
\hline 11 & $\begin{array}{l}\text { Triflin; } 6 \text { "'-O- } \beta \text {-L-ramnopyranosyl,7-O- } \beta \text {-L- } \\
\text { arabinofuranoside }\end{array}$ & I. hebepetala & [26] \\
\hline 12 & Formononetin & I. pseudotinctoria & {$[20]$} \\
\hline 13 & Afromosin & I. pseudotinctoria & [20] \\
\hline 14 & Genistein & I. pseudotinctoria & [20] \\
\hline 15 & Rutin & I. kirilowi & [27] \\
\hline 16 & 7,4'-Dihydroxy-3'-methoxy isoflavone & I. pseudotinctoria & [20] \\
\hline 17 & Formononetin-7-O- $\beta$-D-glucoside & I. pseudotinctoria & [20] \\
\hline 18 & Kaempferol-3-O-rutinoside & I. kirilowi & [27] \\
\hline 19 & Quercetin-3-O-glucosidase & I. kirilowi & [27] \\
\hline 20 & Louisfieserone & I. suffruticosa & [67] \\
\hline 21 & Hetranthin A & I. hetranthaWall. & [28] \\
\hline 22 & Hetranthin B & I. hetranthaWall. & [28] \\
\hline 23 & Glabretephrin & I. tinctoria & [29] \\
\hline 24 & Semiglabrin & I. tinctoria & [29] \\
\hline 25 & Pseudosemiglabrin & I. tinctoria & [29] \\
\hline 26 & Flavonol glycoside & $\begin{array}{l}\text { I. tinctoria, } \\
\text { I. zollingeriana. } \\
\text { I. hebepetala Benth. ex } \\
\text { Baker }\end{array}$ & {$[30,31]$} \\
\hline 27 & Quercetin & $\begin{array}{l}\text { I. aspalathoides } \\
\text { Vahl ex DC. }\end{array}$ & [32] \\
\hline 28 & Kaempferol & $\begin{array}{l}\text { I. aspalathoides } \\
\text { Vahl ex DC. }\end{array}$ & [32] \\
\hline 29 & $\begin{array}{l}\text { kaempferol 5-O-b- } \\
\text { D-glucopyranoside }\end{array}$ & $\begin{array}{l}\text { I. aspalathoides } \\
\text { Vahl ex DC. }\end{array}$ & [32] \\
\hline \multicolumn{4}{|c|}{ Nitro group containing compounds } \\
\hline 30 & Endecaphyllin $\mathrm{A}_{1}$ & I. linnaei & {$[33]$} \\
\hline 31 & Hiptagin & I. endecaphylla & [33] \\
\hline 32 & $\begin{array}{l}\text { 3-Nitropropanoates;2,3,4,6-tetrkis-(3- } \\
\text { nitropropanoyl)- } \beta \text {-D-glucopyranose }\end{array}$ & $\begin{array}{l}\text { I. suffruticosa and } \\
\text { I. linnaei }\end{array}$ & [33] \\
\hline 33 & Endecaphyllin & I. endecaphylla & {$[33]$} \\
\hline 34 & 3-Nitropropanoic acid, Et ester & I. endecaphylla & [33] \\
\hline \multicolumn{4}{|l|}{ Amide } \\
\hline 35 & Indigoidin & I. pseudomonas & {$[34]$} \\
\hline 36 & Indigotin & I. tinctoria & [35] \\
\hline 37 & (S)-Indispicine & $\begin{array}{l}\text { I. spicata and } \\
\text { I. endecaphylla }\end{array}$ & [36] \\
\hline \multicolumn{4}{|c|}{ Steroidal compounds } \\
\hline 38 & $\beta$-Sitosterol & I. pseudotinctoria & {$[20]$} \\
\hline
\end{tabular}


Rahman et.al., Rec. Nat. Prod. (2018) 12:1 1-13

\begin{tabular}{|c|c|c|c|}
\hline S. No. & Compound Name & Source & Ref \\
\hline 39 & Daucosterol & I.pseudotinctoria & [20] \\
\hline 40 & Lupeol & I. kirilowi & [28] \\
\hline 41 & $\begin{array}{l}\text { 5-[(E)-2-(4-hydroxyphenyl] benzene-1,3- } \\
\text { diol }\end{array}$ & Indigoferalinnaei, Ali & [37] \\
\hline 42 & Gitoxin & Indigoferalinnaei, Ali & {$[37]$} \\
\hline \multicolumn{4}{|c|}{ Keto compounds } \\
\hline 43 & 12-Oleanen-3,11-dione & I. pseudotinctoria & [20] \\
\hline 44 & 12-Oleanen-3,11-dione & I. pseudotinctoria & [20] \\
\hline 45 & $3 \beta$-acetoxy-12-oleanen-11-one & I. pseudotinctoria & [20] \\
\hline \multicolumn{4}{|c|}{ Keto flavonoids } \\
\hline 46 & Louisfieserone & I. suffruticosa & [39] \\
\hline \multicolumn{4}{|l|}{ Lignin } \\
\hline 47 & Isoliquiritigenin & I. pseudotinctoria & [20] \\
\hline 48 & Maackiain & I. pseudotinctoria & [20] \\
\hline \multicolumn{4}{|c|}{ Alkaloids } \\
\hline 49 & Indigo, 2,2'-bisindole alkaloid & $\begin{array}{l}\text { I.tinctoria, } \\
\text { I.suffruticosaand } \\
\text { I. truxillensis Kunth. }\end{array}$ & $\begin{array}{l}{[40-42]} \\
{[43]}\end{array}$ \\
\hline \multicolumn{4}{|c|}{ Terpenoids } \\
\hline 50 & Indigoferabietone & $\begin{array}{l}\text { I. longeracemosaBoiv. ex. } \\
\text { Baill. }\end{array}$ & [44] \\
\hline 51 & Two monoterpene glycosides, & I. hetrantha & [45] \\
\hline \multicolumn{4}{|c|}{ Miscellaneous compounds } \\
\hline 52 & Indigin & I. oblongifoliaForssk., & [46] \\
\hline 53 & Indigoferic acid & I. oblongifoliaForssk. & [46] \\
\hline \multicolumn{4}{|c|}{ Toxic constituents of I. spicata } \\
\hline 54 & Indospicine & I. spicata & $\begin{array}{l}{[28,47,48]} \\
{[50,50]}\end{array}$ \\
\hline 55 & Canavanine & I. spicata & {$[28-50]$} \\
\hline 56 & 3-nitropropanoic acid & I. spicata & {$[28-50]$} \\
\hline \multicolumn{4}{|c|}{ Rotenoids } \\
\hline 57 & cis- $(6 a \beta, 12 a \beta)$-hydroxyrotenone & I. spicata & {$[51,52]$} \\
\hline 58 & rotenone & I. spicata & {$[52,53]$} \\
\hline 59 & Tephrosin & I. spicata & {$[52,54]$} \\
\hline \multicolumn{4}{|c|}{ Chalcone } \\
\hline 60 & (+)-tephropurpurin & I. spicata & [55] \\
\hline \multicolumn{4}{|c|}{ Nitropropanoyl } \\
\hline 61 & $\begin{array}{l}{[2,3,4,6 \text {-tetra }} \\
\text { glucopyranose }]\end{array}$ & I.suffruticosa & [56] \\
\hline \multicolumn{4}{|c|}{ Benzofuran } \\
\hline 62 & $\begin{array}{l}\text { 2-(2'-hydroy-4'-methoxypheyl)-3-methyl-6- } \\
\text { methoxy benzo[b] furan }\end{array}$ & I. microcorpa & [57] \\
\hline 63 & $\begin{array}{l}\text { 2-(2'-hydroy-4'-methoxypheyl)-3-methyl- } \\
\text { 5,6-dioxmethyl-ene-benzo[b] furan }\end{array}$ & I. microcorpa & {$[57]$} \\
\hline \multicolumn{4}{|c|}{ Cerebroside } \\
\hline $\begin{array}{l}64 \\
\text { Ester }\end{array}$ & Indigoferamide-A & I. heterantha & [69] \\
\hline 65 & Indigoferate & I. heterantha & [70] \\
\hline
\end{tabular}



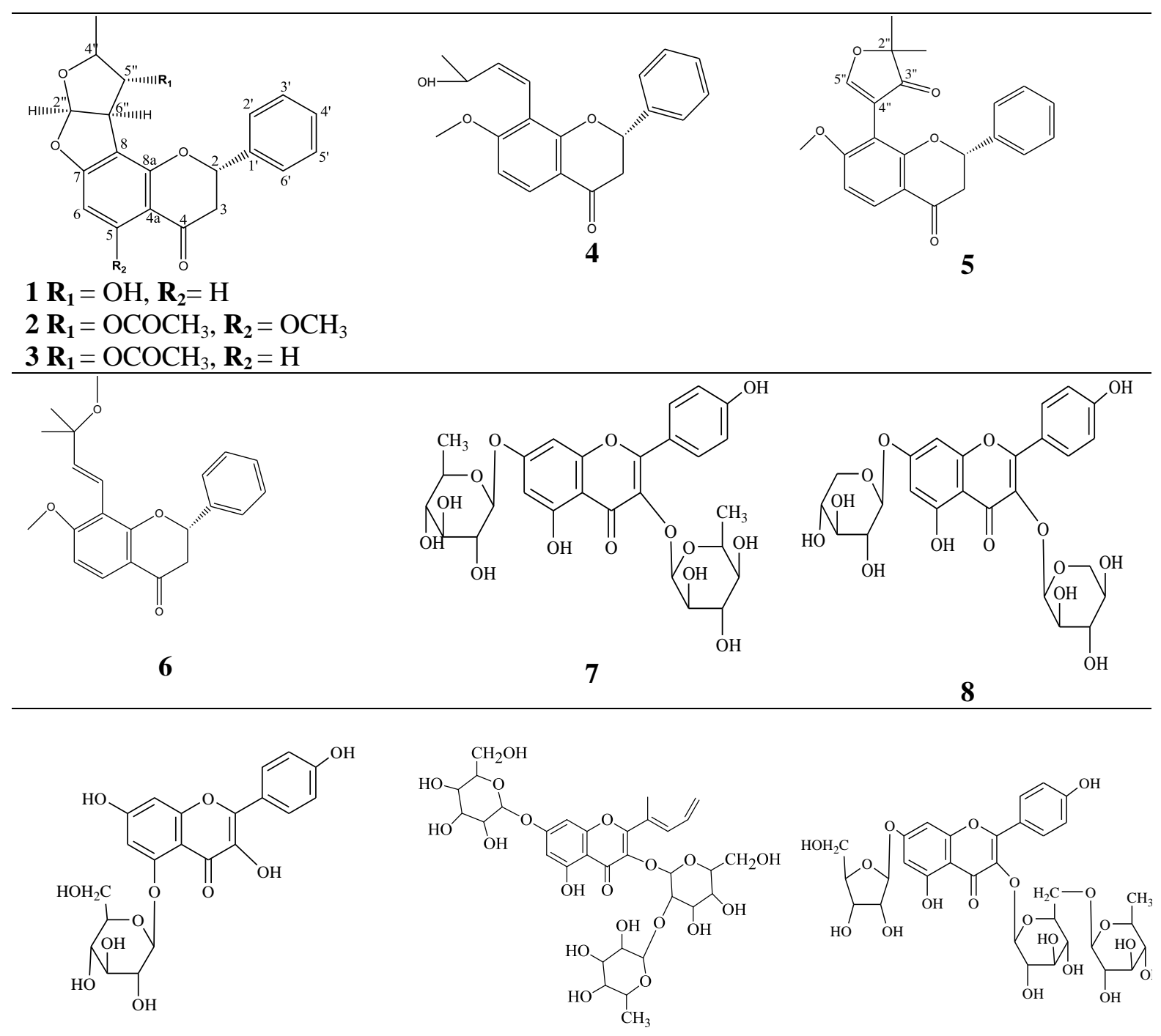

9<smiles>COc1ccc(-c2coc3cc(O)ccc3c2=O)cc1</smiles>

12<smiles>COc1ccc(-c2coc3cc(OC)c(O)cc3c2=O)cc1</smiles>

13<smiles>O=c1c(-c2ccc(O)cc2)coc2cc(O)cc(O)c12</smiles>

14

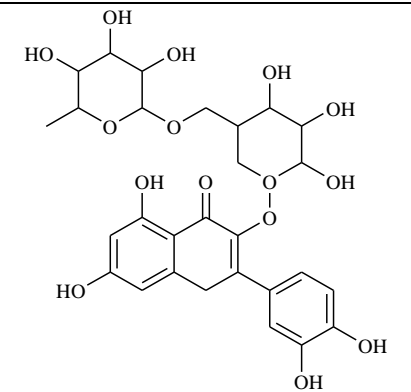

15

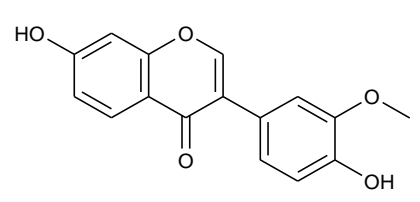

16

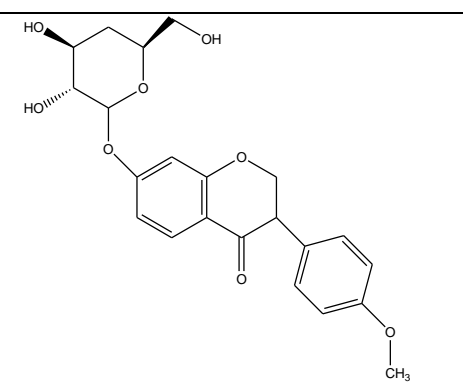

17 
Rahman et.al., Rec. Nat. Prod. (2018) 12:1 1-13
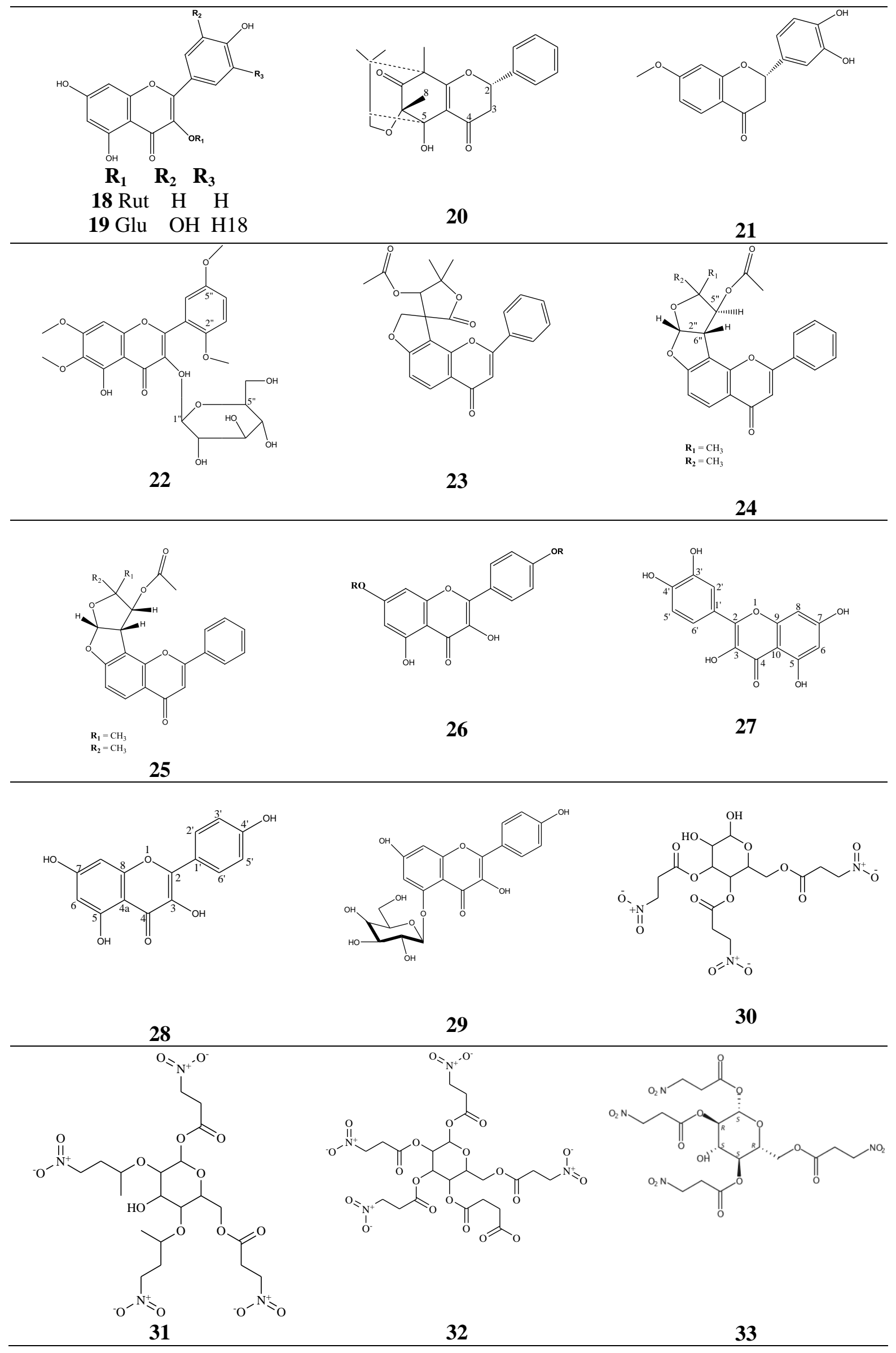
Phytochemistry and pharmacology of genus Indigofera

8<smiles>CCOC(=O)C(C)[N+](=O)[O-]</smiles>

34<smiles>NC1=CC(=C2C=C(N)C(=O)NC2=O)C(=O)NC1=O</smiles>

35<smiles>O=C1/C(=C2\Nc3ccccc3C2=O)Nc2ccccc21</smiles>

36

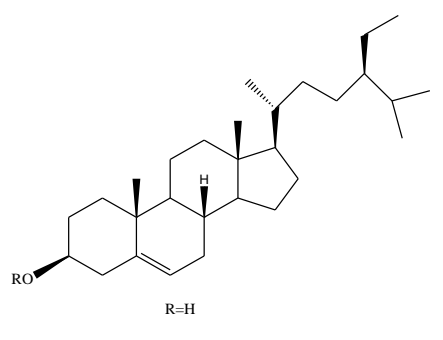

38

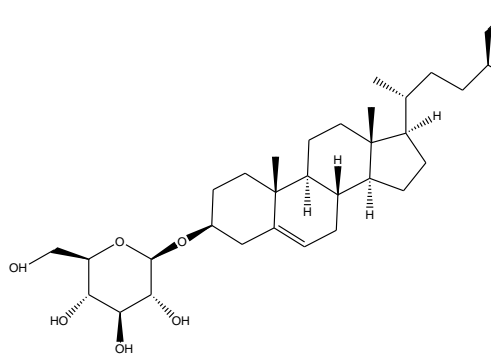

39

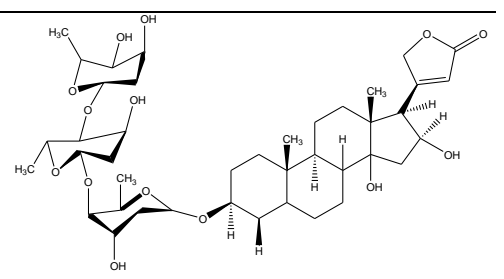

42

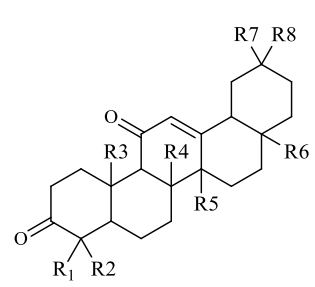

$\mathbf{R}_{\mathbf{1}}=\mathbf{R} \mathbf{2}=\mathbf{R} 3=\mathbf{R} 4=\mathbf{R} 5=\mathbf{R} 6=\mathbf{R} 7=\mathbf{R} 8=\mathrm{CH}_{3}$

43

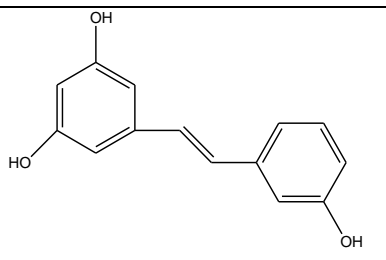

41

42

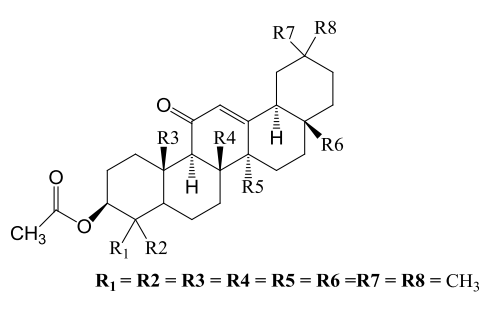

45

44<smiles>O=C(/C=C/c1ccc(O)cc1)c1ccc(O)cc1O</smiles><smiles>C[C@]12COc3cc(O)ccc3[C@@]1(C)Cc1cc3c(cc12)OCO3</smiles>

46

47

48<smiles>O=C1/C(=C2\Nc3ccccc3C2=O)Nc2ccccc21</smiles>
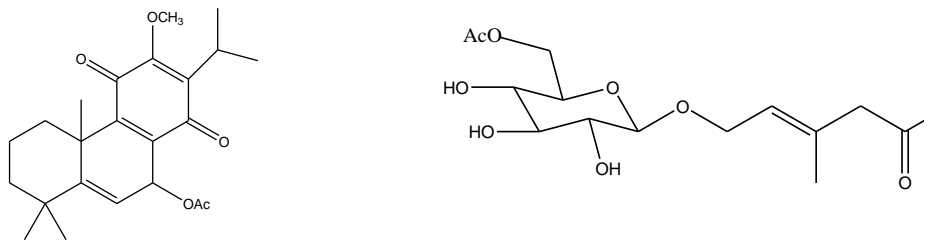
Rahman et.al., Rec. Nat. Prod. (2018) 12:1 1-13
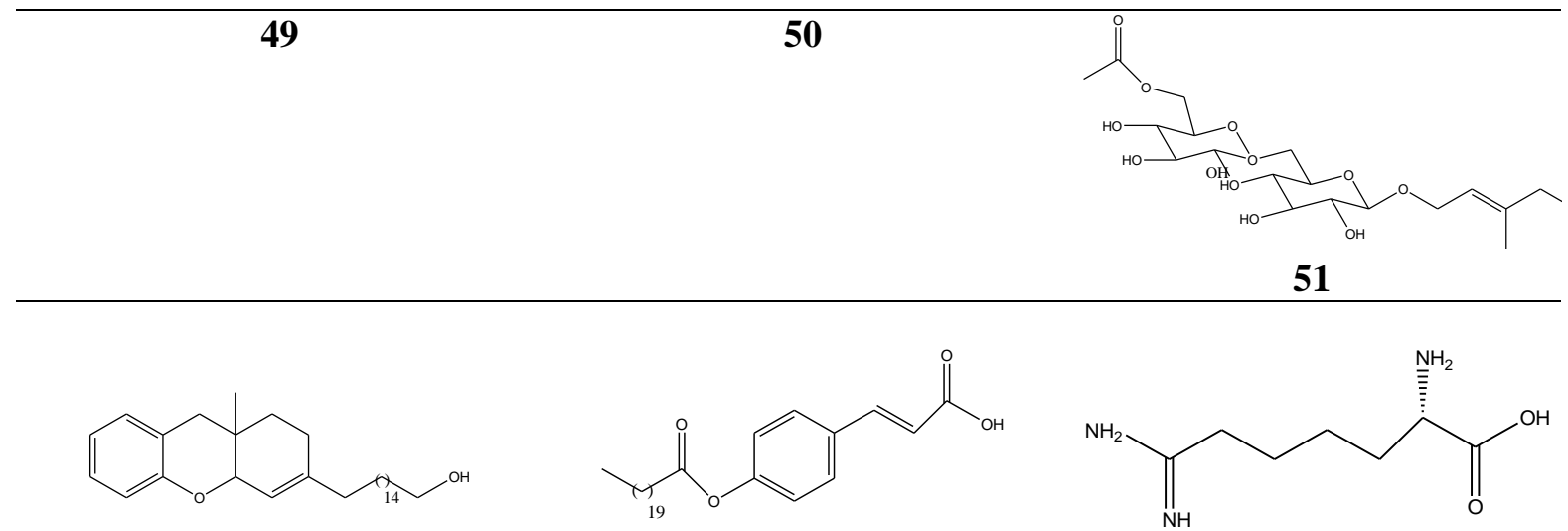

52

53

54

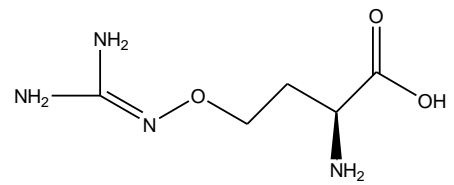<smiles>O=C(O)CC[N+](=O)[O-]</smiles>

55

56

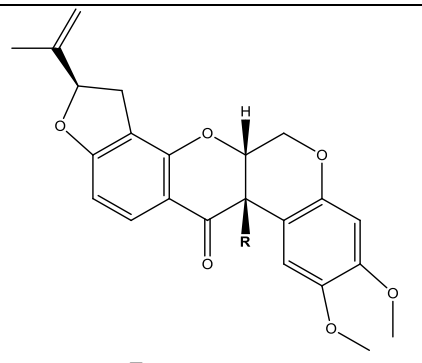

$57 \mathbf{R}=\mathrm{OH}$

$\mathbf{5 8} \mathbf{R}=\mathrm{H}$
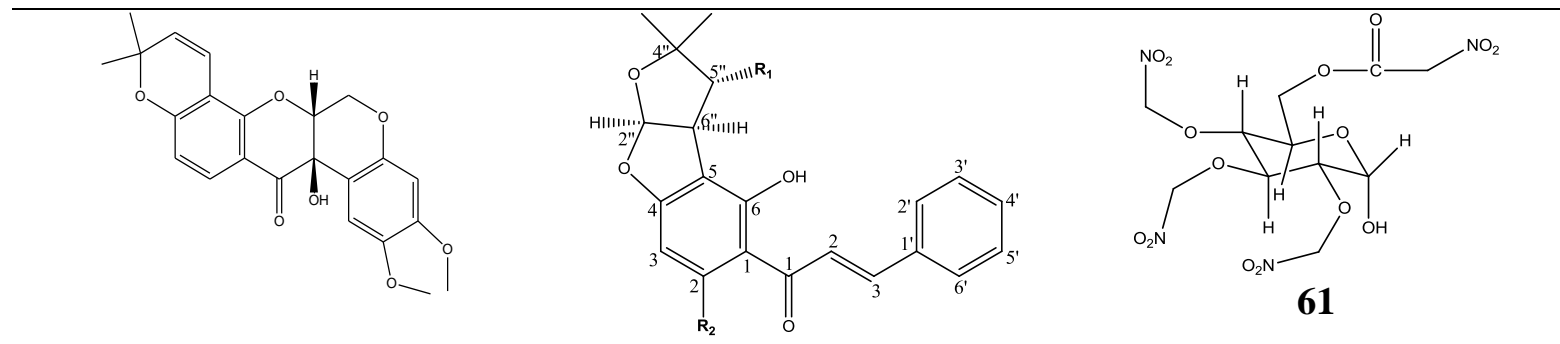

59

$$
\begin{aligned}
& \mathbf{R}_{\mathbf{1}}=\mathrm{OCOCH}_{3} \\
& \mathbf{R}_{\mathbf{2}}=\mathrm{OCH}_{3}
\end{aligned}
$$

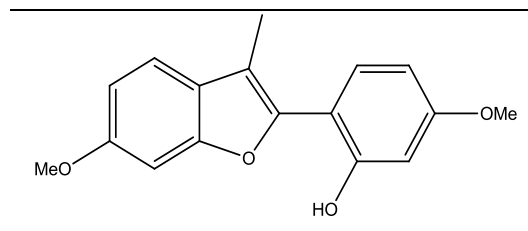

62

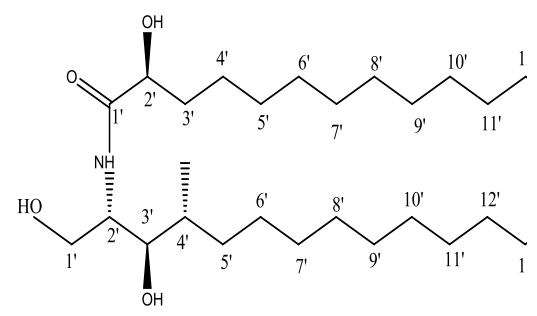

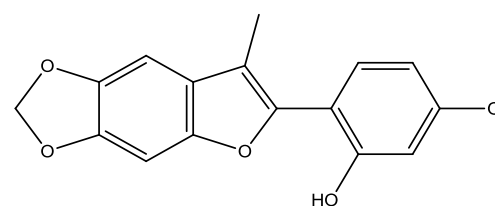

63

Figure 1. Structure of chemical compounds in Indigofera species 
Indigo has also been testified as an isolate of I. suffruticosa and I. truxillensis Kunth [42] [43]. This compound was shown to increase levels of nitric oxide (NO) and tumor necrosis factor- $\alpha$ (TNF- $\alpha$ ) in addition to showing cytotoxicity against LM-2 breast adenocarcinoma and LP07 lung adenocarcinoma cells with $\mathrm{IC}_{50}$ values of 0.9 and $1.4 \mu \mathrm{g} / \mathrm{mL}$, respectively [43]. In adding, indigo pretreatment in rats (2 $\mathrm{mg} / \mathrm{kg}$, p.o.) erstwhile to ethanol-induced gastric ulcer formation exhibited gastro defensive effects of about $80 \%$ suppression of the gastric lesions, when matched to a negative control (with no pretreatment) [42]. The component $I$. bietone with antifungal activity against Candida albicans, has been isolated from I. longeracemosa Boiv. ex. Baill [44]. The various crude sub fractions of extract of seeds of I. heterantha divulged phytotoxic and antifungal action [63] as well as antimicrobial and insecticidal abilities [64]. I. bietone also displayed robust activity against Mycobacterium tuberculosis with a minimum inhibitory concentration (MIC) value of $0.38 \mu \mathrm{g} / \mu \mathrm{L}$, after duration of 21-day incubation period [44]. The MIC value of test compound is the lowest concentration that stopovers the observable growth of bacteria after an overnight incubation period [64] [66]. In addition, this compound showed antibacterial activity against Proteus vulgaris, Escherichia coli and Staphylococcus aureus, with MIC values of 1.5, 0.9, and 0.5 $\mu \mathrm{g} / \mu \mathrm{L}$, respectively, using the disk diffusion method [44].

Two monoterpene glycosides secluded from I. heterantha, were barbed out to exhibit in vitro lipoxygenase inhibition [45]. Both Indigin and indigoferic acid retain lipoxygenase inhibitory action and indigoferic acid also show weak butyrylcholinesterase (BChE) [46]. A lignin besides two acylphloroglucinols isolated from $I$. hetrantha, also revealed lipoxygenase inhibitory activity [58]. Indospicine and canavanine; (arginine inhibitors), and another toxic compound, 3-nitropropanoic acid in the leaves and seeds of this species [21] [48] [49] [50]. Indospicine was found to be teratogenic and to persuade abortion in pregnant animals [67-68]. The various components isolated from the I. heterantha revealed inhibitory activity against the enzyme lipoxygenase [38]. The aqueous acetone extract of $I$. colutea, I. macrocalyx, I. pulchra, I. nigritana and I. tinctoria bared significant antioxidant activity [59]. 3-Nitropropionate is the toxic substance of indigofera [60]. Some species of the genus Indigofera such as I. heterantha is used as herbal medicine as well as folk medicine to treat gastrointestinal disorder and abdominal pain [58]. The various crude extracts of I.tinctoria showed anti hyperglycemic, antibacterial, cytotoxicity, antidiabetic, anti inflamatory, anti epilective, anti hepatoprotective, antihelmenthic, antinoceptive, antiproliferative and antidyslipidemic activities [68]. The methanolic crude extract of $I$. heterantha roots exposed antidiabetic and antioxidant activity [71].

\section{Conclusions}

Although a large numbers of species of genus Indigofera are distributed all over the world, among, these few species were investigated. Phytochemical studies on the plants of this genus had led to the isolation of 65 compounds including terpenoids, flavonoids, lignins, Nitro group containing compounds, steroids and others etc. The chemical constituents and crude extracts of some species of genus Indigofera were found to possess different biological activities. Based on the literature survey the genus has high medicinal importance. Keeping in view the above mentioned literature survey the biological importance of genus Indigofera revealed that chemical exploitation of various species were found to retain different potential biological activities. Thus, much attention should be paid to Indigofera species for further discovery of novel phytochemicals and evaluation of their pharmacological activities. This will help to cope with various diseases by introducing novel therapeutic agents to world health community.

\section{Competing Interests}

Authors have declared that no competing interests exist. 
Rahman et.al., Rec. Nat. Prod. (2018) 12:1 1-13

\section{ORCID}

Taj Ur Rahman: 0000-0003-3869-424X

Muhammad Aurang Zeb: 0000-0001-5841-3500

Wajiha Liaqat: 0000-0003-1102-174X

Muhammad Sajid: 0000-0002-5993-3281

Sajjad Hussain: 0000-0002-4842-3702

M. Iqbal Choudhary: 0000-0001-5356-3585

\section{References}

[1] K.J. Ming, N. Khang, G.L. Sai and C.T. Fatt (2003). (Recent advances in traditional plant drugs and orchids, Acta Pharmacol. Sinica. 24, 7-21

[2] A. Awadh and N.A. Ali (1997). Flora of West Pakistan, National Herbarium Agriculture Research Council, Rawalpindi. 100, 65-83.

[3] Z. K. Shinwari, T. Watanabe, M. Rehman and T. Youshikawa (2006). A pictorial guide to Medicinal Plants of Pakistan. KUST. Kohat, Pakistan.

[4] Anonymous (2001). The Wealth of India. A Dictionary of Indian Raw Materials \& Industrial Products. Council of Scientific \& Industrial Research, New Delhi, India Publications, New Delhi, India. 5, 179-180.

[5] A. Huxley (1992). The New RHS Dictionary of Gardening. Mac Millan Press. 0-333-47494-5.

[6] B. Davis (1990). Climbers and Wall Shrubs. Viking. ISBN 0-670-82929-3.

[7] C.O.A. Esimon, M.U. Dikwu and K.N. Muko (1999). Antibacterial properties of Indigofera dendroides leaves, Fitroterapia. 70, 517-520

[8] P. Oleg and A. Stainton (1985). Flowers of the Himalaya. Oxford University Press, Delhi, 119.

[9] M.U. Dahot (1999). Antibacterial and antifungal activity of small protein of Indigofera oblongifolia leaves, J. Ethnopharmacol. 64, 277-282.

[10] M. Shahjahan, G. Vani and C.S. Devi (2005). Protective Effect of Indigofera oblongifolia in CCl4-induced hepatotoxicity, J. Med. Food. 8, 261-265.

[11] M.S. Abubakar, E. Balogun, E.M. Abdurahman, A.J. Nok, M.M. Shok and M. Garba (2006). Ethnomedical treatment of poisonous snakebites: Plant extract neutralized Naja nigricollis venom, Pharm Biol. 44, 343348.

[12] D. Prakash, S. Suri, G. Upadhyay and B.N. Singh (2007). Total phenol, antioxidant and free radical scavenging activities of some medicinal plants. Int. J. Food Sci. Nutr. 58, 18-28.

[13] P. J. Waako, E. Katuura, P. Smith and P. Folb (2007). East African medicinal plants as a source of lead compounds for the development of new antimalarial drugs, Afr. J. Ecol. 45, 102-106.

[14] R. Chakrabarti, R.K.B. Damarla, R. Mullangi, V.M. Sharma, R.K. Vikramadithyan and R. Rajagopalan (2006). Insulin sensitizing property of Indigofera mysorensis extract, J. Ethnopharmacol. 105,102-106.

[15] M. Hamayun, A. Khan, and M. A. Khan (2003). Common medicinal folk recipes of District Buner, NWFP, Pakistan. Ethnobot. Leafl. 1, 14.

[16] J.S.A. Gamble, B. Singh and M.P. Singh (1972). Manual of Indian Timbers.

[17] K. Nyarko, A. Alexander and S. Rchibald (1998). Indigofera arrecta: Safety evaluation of an antidiabetic plant extract in non-diabetic human volunteers, J. Phytother. Res. 12, 52-54I

[18] B.E. Amala, N. Ganga and R. Arivudainambi (1982). Anti-inflammatory activity of Indigofera aspalathoides Vahl, Ind. J. Med. Res. 76,115-121

[19] M. Umar (1999). Antibacterial and antifungal activity of small protein of Indigofera oblongifolia leaves, J. Ethanopharmacol. 64, 277-282.

[20] P. L. Bueno, L. J. Lantvit, D. D. Pan, L. Ninh, T.N. Chai and H.B. Kinghorn (2013). Bioactive constituents of Indigofera spicata. J. Nat. Prod., 76, 1498-1504.

[21] E.J. Britten, A.L Palafox, M.M. Frodyma and F.T. Lynd (1963). Level of 3-nitropropanoic acid in relation to toxicity of Indigofera spicata in chicks, Crop Sci. 3, 415-416.

[22] D.K. Gupta, M. Krishnamurti and L. Parthasarathi (1980). A new flavanone from Tephrosia purpurea seeds, Phytochemistry 19, 1264-1272.

[23] M.C. Pirrung, Y. R. Lee, A.T. Morehead and A.T. McPhail (1998). Revised relative and absolute stereochemistry of (+)-purpurin. J. Nat. Prod. 23, 89-91.

[24] C.L. Carter and W.J. McChesney (1949). Hiptagenic acid identified as ß-nitropropionic acid, Nature. 166, 575-576. 
[25] Anamem (1997). 3-isopropyl-9a-methyl-1,2,4a,9a-tetrahy-droxanthene: A novel tricyclic compound from the root extract of Xylopia africana (Benth.) oliver (annonacea e), Ind. J. Chem. Sect. B: Org. Chem. Incl. Med. Chem. 36,118-20.

[26] V.N. Shivanar, R. pavala, R. Moorthi and K. Senthamarai (2013). Identification and phytochemical evaluation of ethanolic extract of Indigofera aspalathoides, Int. J. Pharm. Pharmaceut. Sci. 5, 189-196.

[27] Z. Zhongyao (2010). Chemical constituents of Indigofera pseudotinctoria, J. Chin. Mater. Med. 35, 27082712.

[28] S. Subramaniam and P. Ayarivan (2014). Cytokine mediated immunomodulatory properties of kaempferol5-O- $\beta$-Dglucopyranoside from methanol extract of aerial parts of Indigofera aspalathoides Vahl ex DC Swarnalatha, Ayarivan Puratchikody, Int. J. Res. Pharm. Sci, 5, 1-6.

[29] T. Narender, T. Khaliq, A. Puri and R. Chander (2006). Antidyslipidemic activity of furanoflavonoids isolated from Indigofera tinctoria, Bioorg. Med. Chem. 16, 3411-3414.

[30] A. Hasan, I. Ahmad, M. A. Khan and M. I. Choudhary (1996). Two flavonoltriglycosides from flowers of Indigofera hebepetala, Phytochemistry 43, 1115-1118.

[31] A. Hisaeda, K. Matsunami, H. Otsuka and Y. Takeda (2011). Flavonol glycosides from the leaves of Indigofera zollingeriana, J. Nat. Med. 65, 360-363.

[32] S. Swarnalatha, A. Umamaheswari and A. Puratchikody (2015). Immunomodulatory activity of kaempferol 5-O- $\beta$-D-glucopyranoside from Indigofera aspalathoides Vahl ex DC. (Papilionaceae) Med Chem Res. 24, 2889-2897.

[33] A. Hasan, M. Farman, and I. Ahmed (1993). Flavonoid glycosides from Indigofera hebepetala, Phytochemistry, 35, 275-276.

[34] M.A. Souza, L.W. Bieber, A.A. Chiappeta, G.M. Maciel, J.F. DeMello, M.F Delle and I. Messana (1988). Arylbenzofurans from Indigofera microcarpa, Phytochemistry. 27, 1817-9.

[35] R.A. Finnegan, W.H. Mueller (1965). Chemical examination of a toxic extract of Indigofera endecaphylla, J. Pharm. Sci. 5, 1136-1144.

[36] S. Warjeet, S.D. Laitonjam and A. Wangkheir (2011). Comparative study of the major components of the indigo dye obtained from Strobilanthes flaccidifolius and Indigofera tinctoria Linn, Int. J. Plant Physiol. Biochem. 3, 108-116.

[37] M.S. Sandhyavali, P. Sivakamisundari, P.Sharma and V. Murugan (2014). "Phytochemical studies on the aerial parts of Indigofera linnaei, Pharmacophore. 5, 94-97.

[38] M.A. Hegarty, (1971). Synthesis of L-6-amidinonorleucine; L-2-amino-6-amidinohexanoic acid; L-aamino-e-amidinocaproic acid, Aust. J. Chem. 3,371-375.

[39] B. Singh, B.K. Chandan, N. Sharma, V. Bhardwaj, N.K. Satti, V.N. Gupta and O.P. Suri (2006). Isolation, structure elucidation and in vivo hepatoprotective potential of trans-tetracos-15-enoic acid from Indigofera tinctoria Linn, Phytother. Res. 20, 831-839.

[40] R. Han, (1996). Highlight on the studies of anticancer drugs derived from plants in China, Stem Cells 12, 53-63.

[41] G. Eisenbrand, F. Hippe, S. Jakobs and S. Muehlbeyer (2004). Molecular mechanisms of indirubin and its derivatives: novel anticancer molecules with their origin in traditional Chinese phytomedicine. J. Cancer Res. Clin. Oncol. 130, 627-635.

[42] E. F. Silva, M. Cola, T. R. Calvo, V. Barbastefano, A. L. Ferreira, D. P. Michelatto, D.A. Almeida, A. C. H. Lima, C. A.Vilegas and W. S. Brito (2007). Antioxidant activity of indigo and its preventive effect against ethanol-induced DNA damage in rat gastric mucosa, Planta Med. 73, 1241-1243.

[43] F. C. Lopes, M. Calvo, T. R. Colombo, L. L. Vilegas and W. Carlos (2011). Immuno stimulatory and cytotoxic activities of Indigofera suffruticosa (Fabaceae), Nat. Prod. Res. 25, 1796-1806.

[44] D. Thangadurai, M.B. Viswanathan and N. Ramesh (2002). Indigoferabietone, a novel abietane diterpenoid from Indigofera longeracemosa with potential anti tuberculous and antibacterial activity, Pharmazie 57, 714-715.

[45] S. Mehmood, A. Rahman, Z. Ahmad, N. Afza, A. Malik, H. Ahmad and M. I. Choudhary (2008). Monoterpene glycosides from Indigofera hetrantha, Nat. Prod. Res. 22, 1189-1195.

[46] A. Sharif, E. Ahmed, A. Malik, N. Riaz, N. Afza, S. A. Nawaz, M. Arshad, S. Raza, and M. I. Choudhary (2005). Lipoxygenase inhibitory constituents from Indigofera oblongifolia, Arch. Pharm. Res. 28, 761-764.

[47] M.P. Hegarty and A. W. Pound (1968). Indospicine, a new hepatotoxic amino-acid from Indigofera spicata, Nature, 217, 354-355.

[48] C. W. Ford, (1969). Galactomannan from the seed of Indigofera spicata, Aust. J. Chem. 22, 2005-2009.

[49] G.S. Christie, M. Wilson and M.P. Hegarty (1975). Effects on the liver in the rat of ingestion of Indigofera spicata, a legume containing an inhibitor of arginine metabolism, J. Pathol. 117, 195-205.

[50] G.A. Rosenthal (1991). The biochemical basis for the deleterious effects of L-canavanine, Phytochemistry 30, $1055-1058$. 
[51] P. L. Van, D. N. Kimpe, J.P. Mudaheranwa, A. Gasiga, N. Schamp, J.P. Declercq, and M.M. Van (1987). Isolation and structural elucidation of potentially insecticidal and acaricidal isoflavone-type compounds from Neorautanenia mitis, J. Nat. Prod. 50, 349-356.

[52] S. Xu. Gao, Y. M. Valeriote and F. A. Gunatilaka (2011). Pierreiones A-D, solid tumor selective pyranoisoflavones and other cytotoxic constituents from Antheroporum pierrei, J. Nat. prod. 74, 852-856.

[53] E. Dagne, A. Yenesew and P.G. Waterman (1989). Flavonoids and isoflavonoids from Tephrosia fulvinervis and Tephrosia pentaphylla, Phytochemistry 28, 3207-3210.

[54] C.C. Andrei, P.C. Vieira, J.B. Fernandes, M.F. daSilva and E. Rodrigues (1997). Dimethylchromene rotenoids from Tephrosia candida, Phytochemistry 46, 1081-1085.

[55] L.C. Chang, C. Gerhäuser, L. Song, N.R. Farnsworth, J. M. Pezzuto and A. D. Kinghorn (1997). Activityguided isolation of constituents of Tephrosia purpurea with the potential to induce the phase II enzyme, quinone reductase, J. Nat. Prod., 60, 869-873.

[56] S. Walmir, F. Garcez, R. Garcez, K.H. Neli, J.R Antonio and A.D. Silva (1989). Nitropropanoyl glucopyranoside from Indigofera suffruticosa, Phytochemistry 28, 1251-1252.

[57] A.Maria D.M. Souza W.Lothar, A.A. Bieber, G. Chiappeta, M. Maciel, J.F.D. Mello, D.M. Franco and M.S. Irene (1988). Arylbenzofurans from Indigofera microcarpa, Phytochemistry 27, 1817-1819.

[58] A. M. Riaz, H. Ahmad, S.A. Nawaz and M.I. Choudhary (2005). Lipoxygenase inhibiting constituents from Indigofera hetrantha, Chem. Pharmaceut. Bull. 53, 263-266.

[59] S. Bakasso, M. Lamien, C.E. Lamien, M. Keindrebeogo, J. Millogo, A.G. Ouedraogo and A.G. Nacoulma (2008). Polyphenol contents and antioxidant activities of five Indigofera species (Fabaceae) from Burkina Faso, Pak. J. Biol. Sci. 11, 1435-1442.

[60] T.A. Alston, L. Mela and H.J. Bright (1977). 3-Nitropropionate, the toxic substance of Indigofera, is a suicide inactivator of succinate dehydrogenase, PNAS, 9, 3767-3771.

[61] C.C. Culvenor, M.C. Foster and M.P. Hegarty (1971). A total synthesis of indospicine, 6-Amidino-2aminohexanoic acid, Aust. J. Chem. 24, 371-375.

[62] C.L. Carter and M.C. Chesney (1949). Hiptagenic acid identified as beta-nitropropionic acid, Nature, 164, $575-576$

[63] G.Uddin, T.U. Rehman, M.Arfan, W.Liaqat, G.Mohammad and M.I. Choudhary (2011). Phytochemical analysis, antifungal and phytotoxic activity of seeds of medicinal plant Indigofera heterantha Wall. Middle-East J.Sci. Res. 8, 603-605.

[64] G. Uddin, T. U. Rehman, A. Mohammad, L. Wajiha, W. Ullah, M. Ghulam, A. Rauf, I. U, khan and M. I. Choudhary (2011). In-vitro pharmacological investigations of aerial parts of indigofera heterantha J. Med. Plant. Res. 5, 5750-5753.

[65] X.A. Dominguez, C.Martinez, A.Calero, X.A. Dominguez and M. Hinojosa (1978). Louisfieserone, an unusual flavanone from Indigofera suffruticosa, Tetrahedron Lett. 5, 429-432.

[66] J. M. Andrews (2001). Determination of minimum inhibitory concentration, J. Antimicrob. Chemother, 1, 5-16.

[67] M. P. Hegarty and A. W. Pound (1970). Indospicine, a hepatotoxic amino acid from Indigofera spicata: Isolation, structure and biological studies, Aust. J. Biol. Sci. 23, 831-842.

[68] S.N. Motamarri, M. Karthikeyan, S. Rajasekar and V. Gopal, (2012). Indigofera Linn- A phytopharmacological review, Int. J. Res. Pharmaceut. Biomed. Sci, 3, 164-169.

[69] T.U. Rahman, M. Arfan, W. Liaqat, G. Uddin and M.I. Choudhary (2014). Isolation of a novel indigoferamide-A from seeds of Indigoferta heterantha Wall and its antibacterial activity, Rec. Nat. Prod. 4, $412-416$.

[70] T.U. Rahman, G. Uddin, K.F. Khattak, W. Liaqat, G. Mohammad, M.I. Choudhary, A. Wadood and A. Ahmad (2014). Isolation and characterization of a novel ester from seeds of Indigofera heterantha (Wall). J. Nat. Prod. 7, 104-112.

[71] M.A. Zeb, M. Sajid, T.U. Rahman, K.F. Khattak and M.T. Khan (2017). Phytochemical screening, antidiabetic and antioxidant potential of methanolic extract of Indigofera heterantha roots, Int. J. Biosci. 10, 355-360.

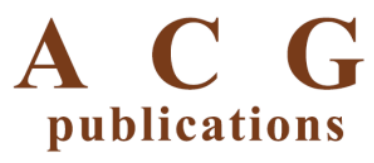

(C) 2017 ACG Publications 